A N N A L E S

UNIVERSITATIS MARIAE CURIE-SKŁODOWSKA

LUBLIN - POLONIA

VOL. XXXIV

SECTIO FF

$1-2016$

\title{
ILONA GUMOWSKA
}

Uniwersytet Marii Curie-Skłodowskiej

\section{Recenzja}

Halina Pelcowa, Stownik gwar Lubelszczyzny, tomy 1-3, Wydawnictwo Uniwersytetu Marii Curie-Skłodowskiej, Lublin 2012-2015.

Stownik gwar Lubelszczyzny autorstwa Haliny Pelcowej wzbogacił się o kolejny, trzeci tom - Świat zwierząt (2015). Jest on kontynuacją dwóch poprzednich prac poświęconych słownictwu z zakresu rolnictwa: tomu I - Rolnictwo: narzędzia rolnicze, prace polowe, zbiór i obróbka zbóż (2012) oraz tomu II - Rolnictwo: transport wiejski, rośliny okopowe i paszowe, gleby i rodzaje pól, uprawa lnu $i$ konopi, zbiór siana (2014). Słownik, w którym integralną część haseł stanowią mapy językowe, można traktować również jako atlas gwarowy. Publikacja wypełnia zatem lukę w opracowaniach dialektologicznych, wśród których brakowało dotychczas słownika i atlasu gwarowego Lubelszczyzny.

Układ słownika i struktura hasła umożliwiają holistyczny opis znaczenia leksyki gwarowej regionu. Zamiarem Autorki jest nie tylko udokumentowanie słownictwa i jego interpretacja, ale także ukazanie dynamiki i kierunku zmian dokonujących się w gwarach. Cel ten zadecydował o niedyferencyjnym charakterze Słownika gwar Lubelszczyzny, w którym oprócz słownictwa typowo gwarowego odnotowywane są wyrazy ogólnopolskie, obecne w mowie mieszkańców wsi regionu. Układ słownika, podzielonego na trzynaście obszernych działów tematycznych, pozwala uporządkować bogaty materiał gwarowy według kryterium semantycznego i zrekonstruować językowy obraz rzeczywistości wiejskiej. Układ taki sprzyja także zachowaniu otwartej struktury słownika, w którym każdy tom stanowi odrębne, samodzielne opracowanie leksyki gwarowej z poszczególnych pól semantycznych. 
Holistyczny opis znaczenia słownictwa występującego w gwarach Lubelszczyzny możliwy jest także dzięki zastosowaniu rozbudowanego hasła słownikowego. Jego siedmioelementowa struktura, podobnie jak struktura całego słownika, pozostaje otwarta. To pozwala Autorce modyfikować hasło w zależności od rodzaju desygnatu. Zaproponowany przez Halinę Pelcową sposób opisu wyrazu gwarowego spełnia wymagania, jakie stoją obecnie przed leksykografią gwarową, zmierzającą do uchwycenia zmian zachodzących w mowie mieszkańców wsi.

Hasło słownikowe składa się z siedmiu komponentów: 1) wyrazu hasłowego, opatrzonego definicją realnoznaczeniową; 2) fotografii, ilustrującej zwłaszcza hasła trudne i nieznane czytelnikowi spoza kręgu użytkowników gwar; 3) kontekstów poświadczających występowanie i użycie wyrazu; 4) źródła udokumentowania wyrazu; 5) geografii słowa, szczegółowej lub uogólnionej, przedstawionej także za pomocą mapy językowej; 6) wariantów fonetycznych i nietypowych form fleksyjnych dotyczących wyrazu hasłowego; 7) odwołania do synonimów i heteronimów występujących w regionie. Zwłaszcza trzy z tych elementów decydują o bardzo dużej wartości naukowej i praktycznej słownika.

Geografia słowa zyskuje wysoki stopień szczegółowości dzięki regionalnemu charakterowi opracowania. Prowadzone od przeszło trzydziestu lat badania terenowe Autorki, a także uzupełnienie bazy materiałowej słownika o dane z: kartoteki Atlasu gwar Lubelszczyzny, Stownika gwar polskich PAN, kwestionariuszy Atlasu gwar polskich oraz materiały z prac magisterskich i licencjackich powstałych pod kierunkiem Haliny Pelcowej, pozwoliły zgromadzić niezwykle bogaty materiał gwarowy. Ilustrują to dane liczbowe dla poszczególnych elementów słownika:

Tabela 1. Słownik gwar Lubelszczyzny w liczbach

\begin{tabular}{|c|c|c|c|c|c|}
\hline Tom & $\begin{array}{c}\text { Liczba } \\
\text { hasel }\end{array}$ & $\begin{array}{c}\text { Liczba } \\
\text { map }\end{array}$ & $\begin{array}{c}\text { Liczba } \\
\text { ilustracji }\end{array}$ & $\begin{array}{c}\text { Liczba wsi, } \\
\text { z których pochodzi } \\
\text { material terenowy }\end{array}$ & $\begin{array}{c}\text { Liczba informatorów, } \\
\text { od których pochodzi } \\
\text { material terenowy }\end{array}$ \\
\hline Tom I & 1206 & 47 & 70 & 468 & 2000 \\
\hline Tom II & 1549 & 55 & 31 & 491 & 2050 \\
\hline Tom III & 2035 & 42 & 46 & 509 & 2070 \\
\hline
\end{tabular}

Tak bogaty materiał pozwolił Autorce stworzyć gęstą siatkę punktów i wybrać reprezentatywną próbę stu czterdziestu czterech miejscowości regionu dla zilustrowania geografii słów.

Drugim elementem, który decyduje o wysokiej wartości naukowej i dokumentacyjnej słownika, są bardzo rozbudowane konteksty wraz z informacjami o miejscu zanotowania. W cytatach Autorka oddaje głos mieszkańcom lubelskich wsi. Dobór oraz liczba kontekstów ma na celu przede wszystkim ukazanie zna- 
czenia oraz sytuacji komunikacyjnej użycia słowa. Cytaty uwzględniają uwarunkowania kulturowe i obyczajowe wyrazu, a także pełnią rolę kwalifikatorów słowa. Rozwiązanie to przynosi dodatkową korzyść dla badaczy języka, ukazuje bowiem wartościowanie poszczególnych elementów rzeczywistości wiejskiej oraz tempo zmian i stosunek, jaki mają do nich mieszkańy wsi. Wybrane przez Autorkę cytaty stanowią cenne źródło dla badaczy frazeologii gwarowej, a także kulturoznawców i folklorystów, gdyż często przywołują informacje o dawnych zwyczajach, obrzędach i wierzeniach.

Trzecim elementem wyróżniającym słownik są barwne fotografie dokumentujące słowa często już dziś nieznane, zapomniane lub wymagające zilustrowania. Jest to z pewnością walor, który poszerza grono odbiorców o osoby nieposiadające przygotowania dialektologicznego czy etnograficznego. Wykorzystanie fotografii, a także prostszego w odbiorze zapisu ortograficznego z uwzględnieniem właściwości gwarowych, nadaje słownikowi charakter opracowania nie tylko naukowego, ale również praktycznego, mogącego stanowić podstawę szkolnej edukacji regionalnej i promocji dziedzictwa językowo-kulturowego Lubelszczyzny.

Stownik gwar Lubelszczyzny, dzięki staraniom Autorki o udokumentowanie i interpretację słownictwa występującego w mowie mieszkańców wsi, zyskuje walor opracowania dialektologicznego, etnolingwistycznego i socjolingwistycznego. Struktura słownika i hasła słownikowego pozwalają nie tylko ocalić od zapomnienia wyrazy dawne, zanotowane w pamięci najstarszego pokolenia, ale także wskazać kierunek i tempo zmian zachodzących w mentalnej przestrzeni wsi lubelskiej. Starannie dobrane konteksty występowania nazw pozwalają badać świadomość językową mieszkańców wsi oraz wartościowanie przez nich przeszłości i teraźniejszości. Tak pomyślany słownik stanowi niezwykle cenny dokument oraz przewodnik po językowym i kulturowym dziedzictwie Lubelszczyzny. 